\title{
The smoking-thrombolysis paradox
}

Ovbiagele and Saver evaluated the effect of smoking on outcome following intravenous thrombolysis for acute ischemic stroke and found that recent smokers who received thrombolysis experienced better early outcomes compared to nonsmokers.

see page 293

\section{Smoke without fire: The complex effects of cigarette smoking on thrombolytic therapy for acute ischemic stroke}

\section{Commentary by Steven R. Levine, MD}

Cigarette use has been linked to progression of existing atherosclerosis, increased fibrinogen, C-reactive protein, and homocysteine $^{1}$ as well as vascular endothelial dysfunction. Smoking's effects on clotting dynamics are more complex, and may depend on patient age and presence of atherosclerosis. Tissue plasminogen activator (t-PA) antigen and activity levels, plasminogen activator inhibitor levels, and fibrin D-dimers have either been normal or elevated in various studies. Markers of thrombin generation in vivo have also been elevated immediately after smoking.

An intriguing observation is that thrombolytic therapy for acute myocardial infarction (MI) is associated with a higher arterial recanalization rate in smokers. ${ }^{2}$ Smokers also have better short-term survival post-MI, primarily due to younger age and more favorable coronary anatomy. This raises the possibility that thrombosis plays a more important role in the pathogenesis of MI in smokers than nonsmokers.

Ovbiagele and Saver have taken this observation and, for the first time, tested it using the National
Institute of Neurological Disorders and Stroke (NINDS) rt-PA Stroke Study data. Among subjects who received t-PA, recent smokers had greater clinical improvement than nonsmokers in median NIH Stroke Scale (NIHSS) at 24 hours compared to baseline. Using a more powerful statistical approach, there was a significant recent smoking $\mathrm{x}$ t-PA interaction for a change in NIHSS at 24 hours suggesting cigarette smoking independently affects short-term outcome after thrombolysis. However, no other smoking $\mathrm{x}$ t-PA interactions for outcomes were found.

There are caveats concerning this post hoc analysis that require further validation. Smokers were defined as anyone who smoked within the year prior to the index stroke. Hence smokers may or may not have been actively smoking. Therefore, we do not know whether the results seen are related to the acute effects of ongoing cigarette exposure, rebound changes in coagulation and hemostasis, or cumulative damage to the vascular endothelium. Improvement in the 24-hour NIHSS was also independently related to lower pretreatment serum glu- cose levels, younger age, and female sex-the first two were significantly more common in smokers. Time to treatment was also 15 minutes on average sooner in smokers. ${ }^{3}$ Speculating on the short term mechanisms: plasminogen has specific affinity for fibrin. t-PA increases the binding of plasminogen to a fibrin clot. Plasminogen activation by t-PA occurs more slowly in the absence of fibrin. Adding fibrin markedly enhances the plasminogen activation rate. Plasminogen activation by t-PA is comparatively inefficient. If there is more fibrin in the acute clots of smokers, thrombolysis could be more effective.

\section{References}

1. Bazzano LA, He J, Muntner P, Vupputuri S, Whelton PK. Relationship between cigarette smoking and novel risk factors for cardiovascular disease in the United States. Ann Intern Med 2003;138:891-897.

2. de Chillou C, Riff P, Sadoul N, et al. Influence of cigarette smoking on rate of reopening of the infarct-related coronary artery after myocardial infarction: a multivariate analysis. J Am Coll Cardiol 1996;27:16621668 .

3. The ATLANTIS, ECASS, and NINDS rt-PA Study Group Investigators. Association of outcome with early stroke treatment: pooled analysis of ATLANTIS, ECASS, and NINDS rt-PA Stroke Trials. Lancet 2004;363:768-774.

see page 293 


\title{
Neurology
}

\author{
July 26 Highlight and Commentary \\ Neurology 2005;65;183 \\ DOI 10.1212/WNL.65.2.183
}

This information is current as of July 25, 2005

\section{Updated Information \&} Services

References

Permissions \& Licensing

Reprints including high resolution figures, can be found at: http://n.neurology.org/content/65/2/183.full

This article cites 3 articles, 0 of which you can access for free at: http://n.neurology.org/content/65/2/183.full\#ref-list-1

Information about reproducing this article in parts (figures,tables) or in its entirety can be found online at:

http://www.neurology.org/about/about_the_journal\#permissions

Information about ordering reprints can be found online:

http://n.neurology.org/subscribers/advertise

Neurology ${ }^{\circledR}$ is the official journal of the American Academy of Neurology. Published continuously since 1951, it is now a weekly with 48 issues per year. Copyright . All rights reserved. Print ISSN: 0028-3878. Online ISSN: 1526-632X.

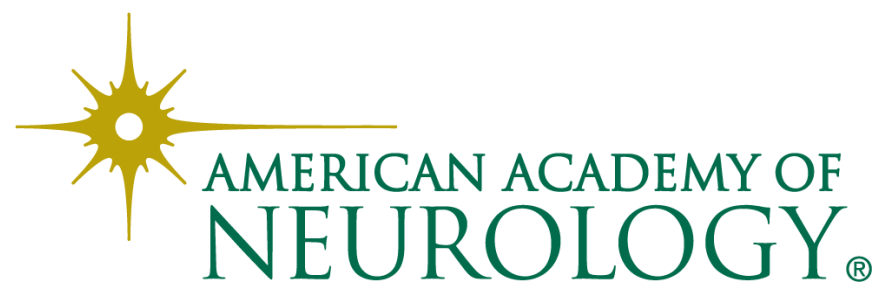

